\title{
Composition of the Fetal and Maternal Guinea Pig throughout Gestation
}

\author{
WILLIAM A. ENGLE AND JAMES A. LEMONS \\ Department of Pediatrics, Indiana University School of Medicine, Indianapolis, Indiana 46223
}

\begin{abstract}
The guinea pig is a small animal species in which the conceptus constitutes a large proportion of maternal weight at term, thereby imposing a major metabolic demand on the mother during pregnancy. In addition the neonatal fat concentration is similar to the human making the guinea pig an interesting model for comparative physiologic study. The purpose of our study was to describe the fetal and maternal physical/chemical growth characteristics of the Hartley albino guinea pig throughout the latter half of gestation. Forty-eight pregnant adult and 122 fetal guinea pigs were sacrificed at intervals throughout gestation and the carcasses analyzed for a variety of growth parameters. The fetal growth rate during the last 8 days of gestation $(5.8 \mathrm{~g} /$ day $)$ was 9.7 times faster than from 30 to $\mathbf{4 0}$ days of gestation $(0.6 \mathrm{~g} / \mathrm{day})$. The fetal mass comprised $55.4 \%$ of the maternal weight gain at term. Fetal energy increased from $403 \mathrm{cal} / \mathrm{g}$ at 30 days to $1950 \mathrm{cal} / \mathrm{g}$ at term and was paralleled by an increase in fetal fat concentration from 0.3 to $9.8 \%$ (wet weight). Nitrogen concentration increased from $0.9 \%$ wet weight at 30 days to $2.6 \%$ at term. An increasing carbon concentration and carbon:nitrogen ratio was also evident. Fetal water concentration declined from 91.6 to $67.8 \%$ during latter gestation. On a wet weight basis, the concentration of fetal sodium remained stable throughout the latter half of pregnancy; potassium, magnesium, iron, calcium, and phosphorus concentrations increased. In contrast to the changes in fetal composition, maternal energy, fat, protein, water, sodium, potassium, calcium, phosphorus, magnesium, and iron concentrations remained relatively constant throughout pregnancy. Therefore, close parallels exist between the guinea pig fetus and human fetus with respect to rates of weight gain as well as energy, fat, protein, water, sodium, calcium, and phosphorus composition. Although dissimilar from the human fetus in respect to potassium, magnesium, iron and "chemical maturity," the fetal guinea pig may be a good model for the study of fetal and perinatal fat matabolism. (Pediatr Res 20: 1156-1160, 1986)
\end{abstract}

During the past decade a number of animal species has been studied with regard to basic metabolic requirements for fetal growth (1). Rather than finding large differences among the various species, remarkable similarities have been identified. As an example, oxygen consumption rates in adult mammals that differ widely in size (guinea pig, rhesus monkey, sheep, cattle, and horse) vary from 2.0 to $9.7 \mathrm{ml} / \mathrm{kg} / \mathrm{min}$; in contrast, the fetuses of these species have similar rates of oxygen consumption, 6 to $8.5 \mathrm{ml} / \mathrm{kg} / \mathrm{min}$.

Received October 21, 1985: accepted June 24, 1986.

Reprint requests Dr. William A. Engle. Department of Pediatrics. Indiana University School of Medicine, 702 Barnhill Drive. Indianapolis, IN 46223.
The principal substrates provided the fetus for energy and growth include glucose and amino acids $(1,2)$. The contribution of fat to fetal nutrient requirements appears to vary among the species. Bovine and ovine fetuses receive negligible quantities of fatty acids from the mother, whereas appreciable placental transfer of fatty acids occurs in the latter part of pregnancy in the human, guinea pig, rat, rhesus monkey, and rabbit (1). Because most information about the nutrient and energy requirements of the mammalian fetus has been collected through studies of large animal species whose fetuses have a relatively low fat content (such as the sheep), we have determined the physical and chemical characteristics of a mammalian species with an appreciable fat content, i.e. the guinea pig. The objectives of this study were: 1) to determine the chemical composition of the fetal and maternal guinea pig throughout latter gestation; and 2) to compare the chemical and physical growth of the fetal guinea pig to data from other mammalian species found in the literature.

\section{MATERIALS AND METHODS}

Animal preparation. Sixty-nine female Hartley albino guinea pigs obtained from a local breeder were studied. Feedings consisted of a standard guinea pig feed supplemented with vitamin C. Of the 69 female guinea pigs, 21 were nonpregnant and 48 were pregnant. The breeding period lasted $72 \mathrm{~h}$ so that gestational ages varied at most by 3 days. Female breeding weights were 450 to $550 \mathrm{~g}$. The number of pregnant guinea pigs killed at 30,40 , 50,60 , and 68 (term) days was $10,8,11,10$, and 9 , respectively. After sacrificing the female guinea pigs with ether and the introduction of bilateral pneumothoraces, both pregnant and nonpregnant animals quickly underwent laparotomy and thoracotomy by a single midline ventral incision extending from the sternal notch to the symphysis pubis. The uterus was excised and, if gravid, fetal and placental tissue was removed. Each fetus, placenta, empty uterus, and maternal carcass (including bowel contents) were weighed and immediately frozen at $-70^{\circ} \mathrm{C}$. The number of fetal guinea pigs examined at $30,40,50,60$, and 68 days was $25,21,26,29$, and 21 , respectively (total 122).

Analytical procedures. All frozen tissue samples were lyophilized in separate containers until constant weight and then homogenized to a fine mixture with a Scovill blender. Weights before freezing and after lyophilization were used to determine the water concentration of each maternal and fetal guinea pig. An aliquot of tissue was then extracted for fat using diethyl ether in a Soxhlet apparatus. A 4-h extraction was found to remove $100 \%$ of the fat when compared to longer extraction periods. Due to limited tissue quantities, 30-day gestation fetal tissues were grouped into three samples for fat extraction. Bomb calorimetry using a Parr 1241 Adiabatic Bomb Calorimeter was performed to determine actual heats of combustion (energy content) for both fat-containing and fat-free samples. Individual samples were studied for all maternal tissues as well as the 50 , 60 , and 68 day fetuses. Forty-day fetuses were combined with littermates into eight groups. All of the 30-day fetuses were 
Table 1. Wet wt of maternal, fetal, and placental tissues*

\begin{tabular}{|c|c|c|c|c|c|}
\hline \multirow{2}{*}{$\begin{array}{c}\text { Gestational } \\
\text { age (days) }\end{array}$} & \multirow[b]{2}{*}{ Maternal $(\mathrm{g})(n)$} & \multicolumn{2}{|c|}{ Fetal } & \multicolumn{2}{|c|}{ Placental } \\
\hline & & Individual $(\mathrm{g})(n)$ & Fetal mass $(\mathrm{g})(n)$ & Individual $(\mathrm{g})(n)$ & Placental mass $(\mathrm{g})(n)$ \\
\hline Nonpregnant & $529 \pm 42(10)$ & & & & \\
\hline 30 & $578 \pm 19(10)$ & $1.0 \pm 0.6(25)$ & $2.5 \pm 1.7(9)$ & $0.9 \pm 0.4(25)$ & $2.3 \pm 1.3(9)$ \\
\hline 40 & $642 \pm 23(8)$ & $7.3 \pm 3.5(21)$ & $19.3 \pm 9.2(8)$ & $2.9 \pm 0.7(21)$ & $7.6 \pm 2.1(8)$ \\
\hline 50 & $680 \pm 41(11)$ & $31.7 \pm 6.3(26)$ & $75.0 \pm 25.6(11)$ & $5.0 \pm 0.7(26)$ & $11.9 \pm 3.5(11)$ \\
\hline 60 & $799 \pm 78(10)$ & $59.1 \pm 11.3(29)$ & $164.1 \pm 47.6(10)$ & $5.6 \pm 1.1(29)$ & $16.2 \pm 3.4(10)$ \\
\hline 68 (term) & $954 \pm 57(9)$ & $105.3 \pm 13.2(21)$ & $235.3 \pm 80.1(9)$ & $5.8 \dagger$ & $13.6 \dagger$ \\
\hline
\end{tabular}

* Mean $\pm \mathrm{SD}$.

† Calculated from equation determined for 30- to 60-day placentas and the average number of placentas per litter being 2.33 .

combined into one group for bomb calorimetry on fat-containing tissues and three groups for fat-free tissues (same groups as for fat extraction). Aliquots of fat-free tisues were analyzed for carbon and nitrogen using an automatic elemental analyzer in conjunction with Midwest Microlabs, Ltd. (Indianapolis, IN) (3$5)$. Precision of this elemental analysis was $\pm 0.3 \%$. Sodium, potassium, iron, magnesium, calcium, and phosphorus were measured by standard analytic methodology on fat-free dry tissue samples.

\section{STATISTICAL ANALYSIS}

Differences among means at each gestational age for each study parameter were compared using a one-way analysis of variance and Tukey's honestly significant difference method for comparisons among means.

\section{RESULTS}

Quantitative changes of fetal, placental, and maternal growth. Throughout gestation the maternal guinea pig gains a total 425 $\mathrm{g}$ which is equivalent to an $80 \%$ weight increase (Table 1). At term the entire maternal weight gain is comprised of $41.4 \%$ maternal tissue, $55.4 \%$ fetal tissue, and $3.2 \%$ placental tissue (Table 1).

The uterus increased in weight from $1.2 \pm 0.4 \mathrm{~g}$ in the nonpregnant condition to $17.9 \pm 1.8 \mathrm{~g}$ at term. Despite this 18 fold increase in weight, the contribution to overall maternal weight gain by the uterus actually declined from 10.6 to $3.9 \%$ during the latter half of gestation.

The weight of the guinea pig fetus increased from $1.0 \pm 0.6 \mathrm{~g}$ at 30 days gestation to $105.3 \pm 13.2 \mathrm{~g}$ at term (Fig. 1). This trend in weight is similar for the entire fetal mass within a litter (Table 1). The rate with which the fetus gains weight also increased throughout latter gestation (Fig. 1). From 30 to 40 days gestation the fetus gained $0.6 \mathrm{~g} /$ day; during the last 8 days of gestation, the fetus gained $5.8 \mathrm{~g} /$ day.

Qualitative changes in fetal, maternal, and placental tissue. Energy Concentration. The energy concentration of the maternal carcass remained essentially unchanged throughout gestation (Table 2). The ranges of energy concentration for the fat-free and entire maternal wet weight carcass were $1396 \pm 99$ to $1515 \pm 94$ $\mathrm{cal} / \mathrm{g}$ and $1781 \pm 298$ to $2062 \pm 123 \mathrm{cal} / \mathrm{g}$, respectively.

As gestation advanced from 30 days to term, the energy concentration of the entire wet weight fetal guinea pig increased from $446 \mathrm{cal} / \mathrm{g}$ to $1941 \pm 156 \mathrm{cal} / \mathrm{g}$ (Table 2). The daily gain in calories throughout this period averaged $39.3 \mathrm{cal} /$ day. Although the energy concentration of the fat-free guinea pig also increased throughout latter gestation on a wet weight basis (Table 2), the daily increase was less than for the entire fetal guinea pig (27.8 versus $39.3 \mathrm{cal} /$ day, respectively). For fetuses beyond 40 days gestation, differences among mean energy concentrations for the entire and fat-free guinea pig were significant $(p<0.01)$.

Fat Concentration. The fat concentration for the fetal and maternal wet weight samples are represented in table 2 . The fat concentration of the maternal carcass remained unchanged dur-

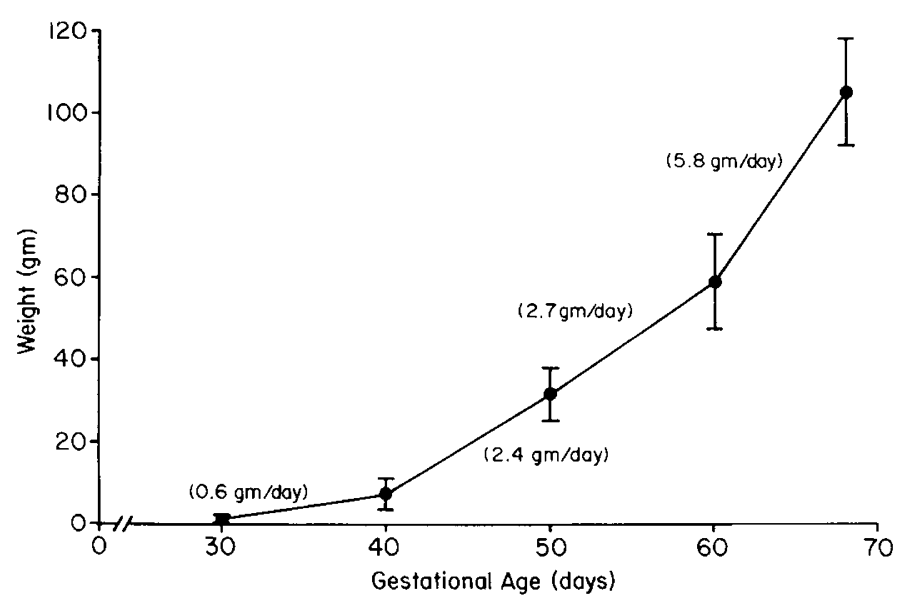

Fig. 1. Fetal growth. Fetal weight $(g$, mean $\pm \mathrm{SD}$ ) is plotted along the vertical axis and gestational age (days) along the horizontal axis. $p<$ 0.001 for weights at 30 versus 40,40 versus 50,50 versus 60 , and 60 versus 68 days. Rate of weight gain during successive intervals in gestation is indicated $(\mathrm{g} /$ day $)$.

ing gestation. The fat concentration of the fetal guinea pig, in contrast, increased by a factor of 31 . At 30 days gestation the fetal guinea pig carcass was $0.3 \%$ fat and at term was $9.8 \%$ fat (Table 2). Beyond 40 days gestation the fetal wet weight fat concentration at each gestational age was significantly different from the fat concentrations at the other gestational ages $(p<$ $0.01)$.

Nitrogen and Carbon Concentration. The maternal carcass contained $\sim 2.5 \%$ nitrogen throughout gestation (Table 2 ). This is equivalent to $15.8 \%$ protein (wet weight) based on the assumption that nitrogen comprises $16 \%$ of biologic proteins (6). In contrast to the maternal carcass, the nitrogen concentration of the guinea pig fetus increased significantly from $1.1 \%$ at 40 days gestation to $2.6 \%$ at term ( $p<0.01$, Table 2 ). In terms of protein concentration, these values are equivalent to 5.6 and $16.3 \%$, respectively.

The concentration of carbon and the carbon:nitrogen ratio in the maternal carcass were stable throughout gestation (Table 2), whereas the fetal guinea pig accrued a significantly increasing concentration of carbon beyond 40 days gestation $(p<0.01)$. The rising carbon:nitrogen ratio reflects the accumulation of fat ( $78 \%$ carbon, $10 \%$ nitrogen) in preference to protein $(50 \%$ carbon, $16 \%$ nitrogen) by the fetal guinea pig $(6,7)$.

Water Concentration. The water concentration of the maternal guinea pig carcass (after removal of the fetal tissue) remained constant throughout gestation at $\sim 67 \%$ (Table 2 ). This contrasted with the significant decline in water fraction of the fetal carcass at each gestational age $(p<0.01)$. The fetus at 30 days gestation was comprised of $91.6 \%$ water by weight; at term the proportion of water had diminished to $67.8 \%$ (very similar to that of the maternal guinea pig). The placental water content was unchanged at $84 \%$ throughout the study period. 


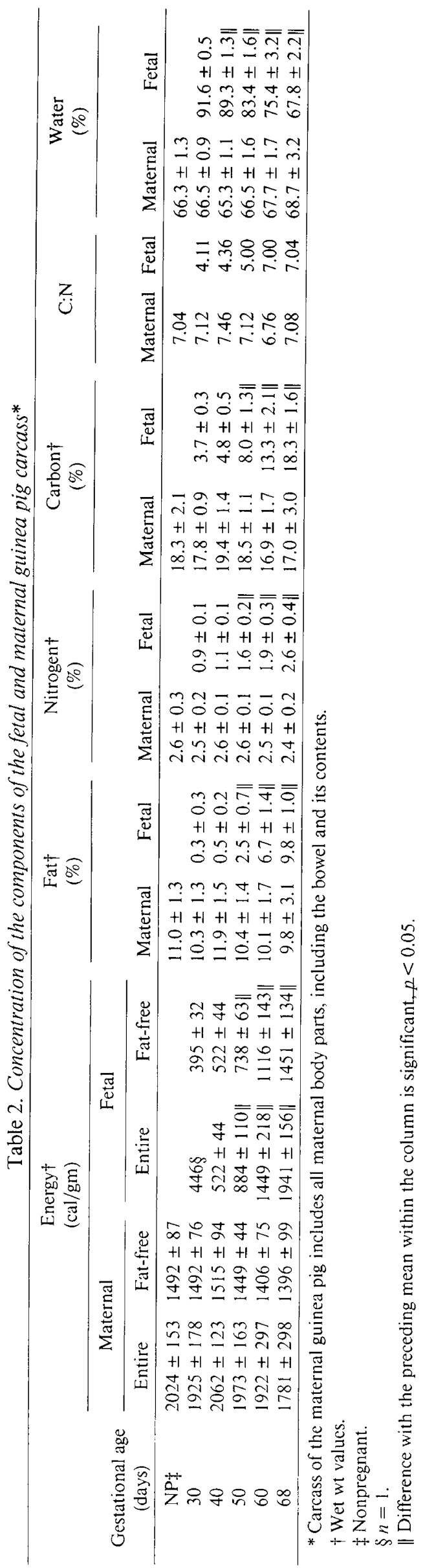

Mineral concentration (Tables 3 and 4). Sodium and potassium. The wet weight sodium concentration for the maternal and fetal guinea pig were similar throughout the latter half of gestation ( 0.19 and $0.20 \%$, respectively). The maternal potassium concentration was stable at $\sim 0.34 \%$, whereas the fetal potassium concentration doubled from $0.18 \%$ at 30 days gestation to 0.33 $\pm 0.03 \%$ at term.

Calcium and phosphorus. The maternal calcium and phosphorus levels remained relatively stable throughout latter gestation ranging from 1.21 to $1.50 \%$ for calcium and 0.77 to $0.95 \%$ for phosphorus (wet weight). Calcium and phosphorus concentrations rose significantly throughout the latter half of gestation for the fetal guinea pig carcass reflecting an increasing contribution of bone to the fetal carcass $(p<0.01)$. At term, the fetus was composed of $1.43 \%$ calcium and $0.90 \%$ phosphorus which is similar to that of the maternal carcass.

Magnesium. The maternal wet weight magnesium fraction was stable throughout pregnancy at 0.080 to $0.095 \%$. The proportion of magnesium in the fetus increased significantly from $0.027 \%$ at 40 days gestation to $0.084 \%$ at term $(p<0.01)$.

Iron. Fetal iron content approached that of the adult guinea pig carcass by term, 0.007 and $0.009 \%$, respectively.

Daily Nutrient Accretion. The daily accretion of individual body constituents of the fetal guinea pig is found in Table 5 . It is evident that the fetus exerts a progressively greater demand on the maternal guinea pig throughout latter gestation for all body constituents measured.

\section{DISCUSSION}

The physical (weight) and chemical (energy, fat, protein, water, and mineral) changes in the fetal and maternal guinea pig during the latter half of gestation have been described. As many similarities in fetal growth requirements exist between species, we have compared our data with those for the human, sheep and bovine fetus (Table 6$)(8-10)$.

The gain in weight throughout latter gestation for the guinea pig fetus is consistent with previous observations of Draper (11). When both gestational age and weight throughout gestation are normalized based on a $100 \%$ value at term for the guinea pig, human, and sheep fetus, similar growth curves became apparent (Fig. 2) (8, 9).

Quantitatively fetal growth rate appears to be comparable for the guinea pig, human, and sheep fetus; however, there are substantial qualitative differences among the three species in terms of fetal composition. The guinea pig and human fetus substantially increase their energy concentrations, whereas the sheep fetus demonstrates a relatively small change during gestation (Fig. 3). The fetal guinea pig nonfat tissues accrue energy at a rate of $27.8 \mathrm{cal} /$ day during the last half of gestation (derived from Table 2). The entire fetus (nonfat and fat tissues) accrues energy at nearly 1.5 times the rate as nonfat tissues $(39.3 \mathrm{cal} /$ day). Therefore, the guinea pig fetus stores energy largely due to fat accumulation during latter gestation.

The pattern of change in fat concentration throughout latter gestation is similar for the human and guinea pig fetus; this contrasts with the relatively small increments in fat in the sheep fetus (Fig. 4). At term, therefore, the fat concentrations of the guinea pig fetus $(9.8 \%)$ and human fetus $(11.6 \%)$ are much greater than that of the sheep fetus $(2.1 \%)$. This similarity in fat accumulation for the human and guinea pig fetus has been noted previously $(7,12)$. Adolph and Heggeness (12) also studied the fat accretion of the fetal hamster, rat, rabbit, and pig; they found very little prenatal fat accumulation in these species, similar to that observed for the fetal lamb $(\sim 2 \%$ fat at term $)(9,12)$.

The changes in protein concentration throughout gestation are similar for fetal guinea pigs, humans, and sheep (Fig. 5), whereas the pattern with which water accumulates differs (Fig. 6). The guinea pig fetus and human fetus have substantial reductions in water content to 68 and $72 \%$, respectively, by term. The sheep 
Table 3. Maternal mineral concentrations (wet wt)*

\begin{tabular}{|c|c|c|c|c|c|c|c|}
\hline $\begin{array}{c}\text { Gestational Age } \\
\text { (days) }\end{array}$ & $n$ & $\begin{array}{l}\text { Sodium } \\
(\%)\end{array}$ & $\begin{array}{c}\text { Potassium } \\
(\%)\end{array}$ & $\begin{array}{l}\text { Calcium } \\
(\%)\end{array}$ & $\begin{array}{c}\text { Phosphorus } \\
(\%)\end{array}$ & $\begin{array}{c}\text { Magnesium } \\
(\%)\end{array}$ & $\begin{array}{l}\text { Iron } \\
(\%)\end{array}$ \\
\hline Nonpregnant & 9 & $0.18 \pm 0.01$ & $0.34 \pm 0.02$ & $1.50 \pm 0.29$ & $0.95 \pm 0.16$ & $0.095 \pm 0.011$ & $0.008 \pm 0.001$ \\
\hline 30 & 9 & $0.18 \pm 0.01$ & $0.34 \pm 0.03$ & $1.21 \pm 0.25$ & $0.77 \pm 0.12$ & $0.089 \pm 0.010$ & $0.009 \pm 0.001$ \\
\hline 40 & 7 & $0.20 \pm 0.02 \dagger$ & $0.36 \pm 0.02$ & $1.26 \pm 0.23$ & $0.82 \pm 0.15$ & $0.091 \pm 0.013$ & $0.009 \pm 0.001$ \\
\hline 50 & 11 & $0.20 \pm 0.01$ & $0.34 \pm 0.02$ & $1.42 \pm 0.40$ & $0.87 \pm 0.22$ & $0.090 \pm 0.015$ & $0.008 \pm 0.001$ \\
\hline 60 & 9 & $0.19 \pm 0.01$ & $0.35 \pm 0.03$ & $1.49 \pm 0.40$ & $0.90 \pm 0.21$ & $0.089 \pm 0.012$ & $0.007 \pm 0.001$ \\
\hline 68 & 9 & $0.18 \pm 0.02$ & $0.32 \pm 0.03$ & $1.24 \pm 0.29$ & $0.77 \pm 0.18$ & $0.080 \pm 0.011$ & $0.009 \pm 0.002 \dagger$ \\
\hline
\end{tabular}

* Mean $\pm 1 \mathrm{SD}$.

$\dagger$ Difference with the preceding mean within the column is significant, $p<0.05$.

Table 4. Fetal mineral concentrations (wet wt)*

\begin{tabular}{|c|c|c|c|c|c|c|c|}
\hline $\begin{array}{c}\text { Gestational Age } \\
\text { (days) }\end{array}$ & $n$ & $\begin{array}{l}\text { Sodium } \\
(\%)\end{array}$ & $\begin{array}{c}\text { Potassium } \\
(\%)\end{array}$ & $\begin{array}{c}\text { Calcium } \\
(\%) \\
\end{array}$ & $\begin{array}{c}\text { Phosphorus } \\
(\%)\end{array}$ & $\begin{array}{c}\text { Magnesium } \\
(\%)\end{array}$ & $\begin{array}{c}\text { Iron } \\
(\%)\end{array}$ \\
\hline 30 & 1 & 0.20 & 0.18 & 0.02 & 0.08 & 0.026 & 0.002 \\
\hline 40 & 7 & $0.19 \pm 0.02$ & $0.19 \pm 0.01$ & $0.15 \pm 0.06$ & $0.14 \pm 0.04$ & $0.027 \pm 0.004$ & $0.003 \pm 0.001$ \\
\hline 50 & 21 & $0.20 \pm 0.01$ & $0.24 \pm 0.01 \dagger$ & $0.50 \pm 0.10$ & $0.34 \pm 0.06 \dagger$ & $0.042 \pm 0.006 \dagger$ & $0.004 \pm 0.001$ \\
\hline 60 & 27 & $0.21 \pm 0.01$ & $0.27 \pm 0.02 \dagger$ & $1.03 \pm 0.31 \dagger$ & $0.66 \pm 0.17 \dagger$ & $0.066 \pm 0.012 \dagger$ & $0.007 \pm 0.001 \dagger$ \\
\hline 68 & 19 & $0.20 \pm 0.02$ & $0.33 \pm 0.03 \uparrow$ & $1.43 \pm 0.34 \dagger$ & $0.90 \pm 0.18 \dagger$ & $0.084 \pm 0.009 \dagger$ & $0.007 \pm 0.001$ \\
\hline
\end{tabular}

* Mean $\pm 1 \mathrm{SD}$.

$\dagger$ Difference with the preceding mean within the column is significant, $p<0.05$.

Table 5. Daily accretion of nutrients by the fetal guinea pig

\begin{tabular}{|c|c|c|c|c|c|c|c|c|c|c|c|}
\hline $\begin{array}{l}\text { Interval } \\
\text { in gestation } \\
\text { (days) }\end{array}$ & $\begin{array}{l}\text { Water } \\
(\mathrm{g})\end{array}$ & $\begin{array}{c}\text { Energy } \\
\text { (kcal) }\end{array}$ & $\begin{array}{l}\text { Fat } \\
(\mathrm{g})\end{array}$ & $\begin{array}{l}\text { Nitrogen } \\
(\mathrm{mg})\end{array}$ & $\begin{array}{c}\text { Carbon } \\
\text { (g) }\end{array}$ & $\begin{array}{l}\text { Sodium } \\
(\mathrm{mg})\end{array}$ & $\begin{array}{l}\text { Potassium } \\
\text { (mg) }\end{array}$ & $\begin{array}{l}\text { Calcium } \\
(\mathrm{mg})\end{array}$ & $\begin{array}{l}\text { Phosphorus } \\
\text { (mg) }\end{array}$ & $\begin{array}{l}\text { Magnesium } \\
\text { (mg) }\end{array}$ & $\begin{array}{l}\text { Iron } \\
\text { (mg) }\end{array}$ \\
\hline $30-40$ & 0.56 & 0.336 & 0.003 & 7.1 & 0.03 & 1.19 & 1.21 & 1.08 & 0.94 & 0.17 & 0.02 \\
\hline $40-50$ & 1.99 & 2.421 & 0.076 & 42.7 & 0.22 & 5.27 & 6.22 & 14.48 & 9.76 & 1.13 & 0.10 \\
\hline $50-60$ & 1.81 & 5.761 & 0.317 & 61.6 & 0.53 & 5.75 & 8.35 & 45.02 & 28.23 & 2.57 & 0.29 \\
\hline $60-68$ & 3.35 & 14.844 & 0.794 & 201.9 & 1.43 & 10.81 & 23.49 & 112.13 & 69.71 & 6.18 & 0.40 \\
\hline
\end{tabular}

Table 6. Comparison of the composition of fetal and adult animals (all results are expressed per $100 \mathrm{~g}$ of fat-free body tissue)

\begin{tabular}{lccccc}
\hline & \multicolumn{2}{c}{ Guinea pig } & & \multicolumn{2}{c}{ Human } \\
\cline { 2 - 3 } \cline { 5 - 6 } \cline { 5 - 6 } & Term fetus & Adult & & Term infant (17) & Adult (17) \\
\hline Protein (g) & 18.1 & 18.3 & & 13.0 & 19.4 \\
Water (g) & 75.2 & 74.6 & & 82.5 & 72.8 \\
Sodium (mg) & 202 & 176 & & 228 & 217 \\
Potassium (mg) & 334 & 332 & & 202 & 280 \\
Calcium (mg) & 1429 & 1484 & & 970 & 2305 \\
Magnesium (mg) & 84 & 94 & & 29 & 45.5 \\
Phosphorus (mg) & 911 & 943 & & 560 & 1345 \\
Iron (mg) & 7.0 & 8.0 & & 9.0 & 7.4 \\
\hline
\end{tabular}

fetus at term is composed of $82 \%$ water. In summarizing these comparative data, the fetal growth of the guinea pig and human are remarkably similar with respect to energy, fat, protein, and water concentrations.

Total fetal caloric requirements are the sum of the energy accrued in new tissues (growth component) and the energy needed for production/maintenance of tissues (metabolic component). From the standpoint of an "average" 64 day fetus who weighs $82 \mathrm{~g}$, energy accrued is $181 \mathrm{kcal} / \mathrm{kg} /$ day. The metabolic component of the total fetal caloric requirement is more difficult to measure in a small animal species such as the guinea pig. Assuming that the guinea pig fetus relies on oxidative metabolism, energy requirements may be estimated from the oxygen consu mption rate. The latter has been measured by Bohr (13) as the $\mathrm{d}_{\mathrm{i}}$ rerence between the oxygen consumption rate of the

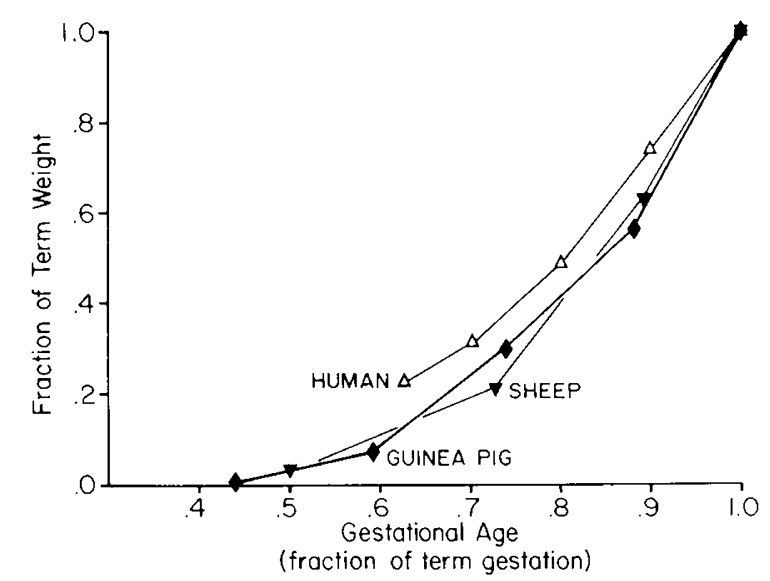

Fig. 2. Fetal growth of the human $(\Delta)$, sheep $(\nabla)$, and guinea pig ( $\triangleleft)$ normalized for weight and gestational age.

pregnant guinea pig before and after delivery of the fetus. In this manner, the oxygen consumption of the fetal guinea pig has been estimated to be $\sim 8.5 \mathrm{ml} / \mathrm{min} / \mathrm{kg}$ body weight (13). Conversion of milliliters oxygen consumed by the fetus to caloric equivalents is based on the fact that $\sim 4.9 \mathrm{kcal}$ energy are produced per liter of oxygen consumed during the oxidative catabolism of carbohydrate and protein (2). With these assumptions, the fetal guinea pig during the last 8 days of gestation would require $60 \mathrm{kcal} / \mathrm{kg} /$ day for oxidative metabolism. The total fetal caloric requirement (metabolic plus tissue accretion), therefore, would be $\sim 241 \mathrm{kcal} /$ $\mathrm{kg} /$ day. This caloric requirement is substantially higher than 


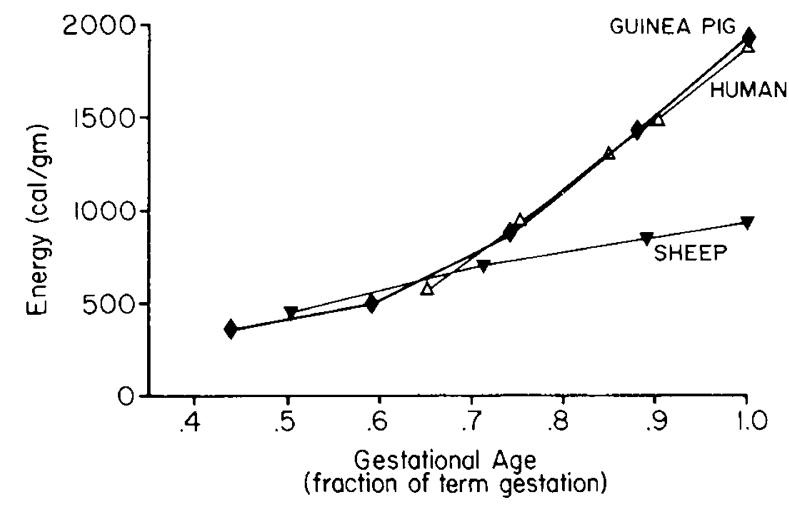

Fig. 3. Fetal energy concentration for the human $(\triangle)$, sheep $(\nabla)$, and guinea pig $(\bullet)$ (wet weight).

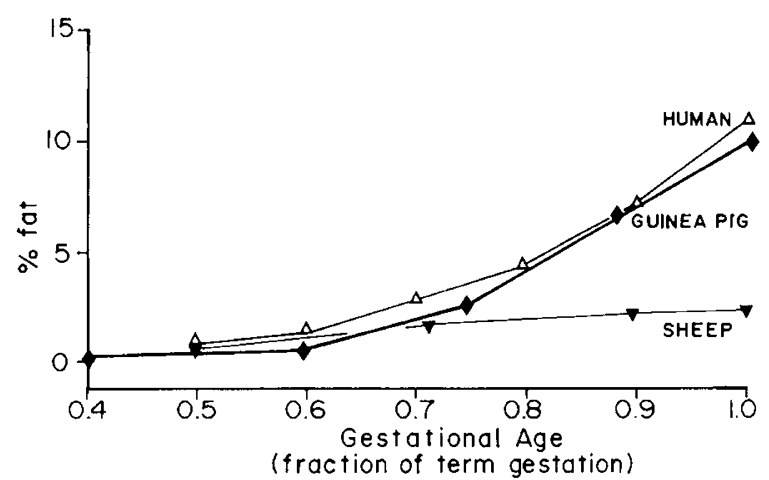

Fig. 4. Fetal fat concentration for the human $(\Delta)$, sheet $(\nabla)$, and guinea pig $(\diamond)$ (wet weight).

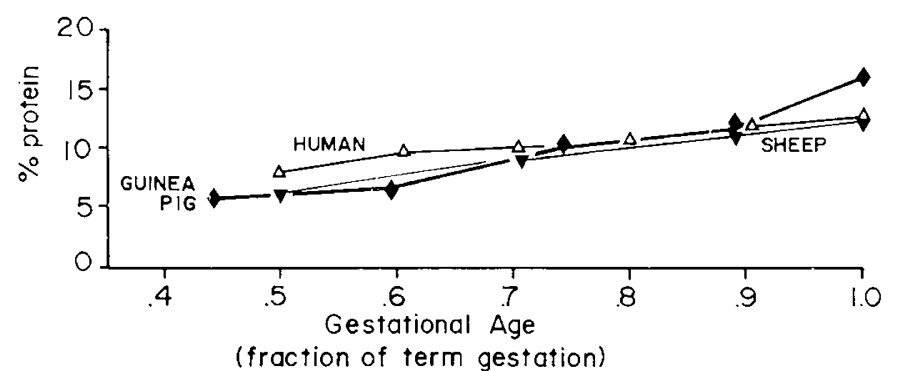

Fig. 5. Fetal protein concentration for the human $(\Delta)$, sheep $(\nabla)$, and guinea pig ( $\bullet$ (wet weight).

estimates for mature ovine ( $88 \mathrm{kcal} / \mathrm{kg} /$ day) (1) and human fetuses ( $96 \mathrm{kcal} / \mathrm{kg} /$ day) (14).

Concentration changes in minerals by the fetal guinea pig, calf, and human are similar for sodium, calcium, and phosphorus $(8,10,15)$. The fetal guinea pig and fetal calf are similar for magnesium and iron accumulation. whereas potassium accumulation is similar for the fetal calf and human $(8,10,15)$. Inferences from these descriptive data about comparative physiologic principles are difficult to formulate.

It is of interest that the energy, fat, protein, and mineral contents of the term guinea pig fetus are strikingly similar to that of the maternal animal (Table 6). These findings support the conclusion drawn by others that the guinea pig fetus at term is chemically and physiologically more mature than other mammals, including man $(15,16)$. The similarities of the adult female and term guinea pig are in contrast to the differences in the adult human and term infant (Table 6).

In conclusion, the growth rate throughout latter gestation of

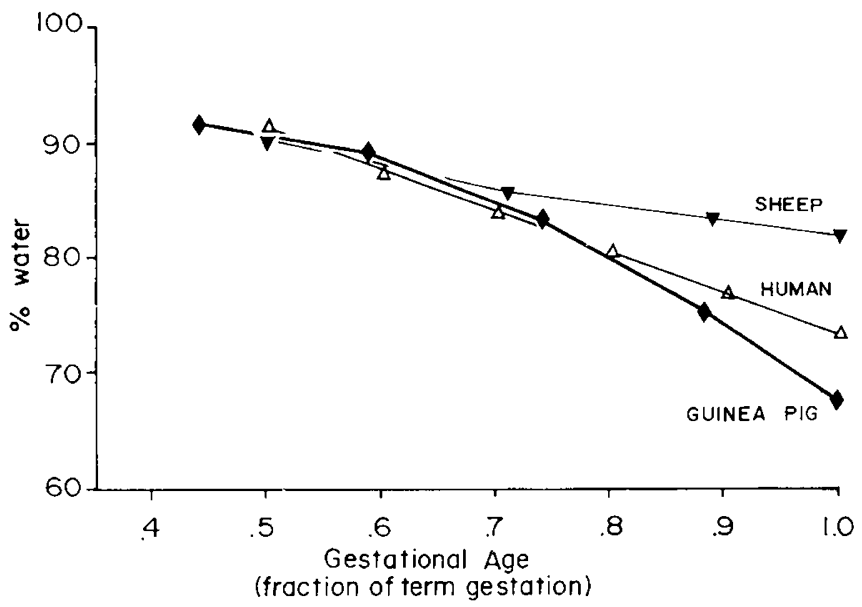

Fig. 6. Fetal water concentration for the human $(\Delta)$, sheep $(\nabla)$, and guinea pig $(\bullet)$ (wet weight).

the fetal guinea pig parallels that of the human fetus in many respects, including rates of weight gain, as well as changes in energy, fat, protein, water, sodium, calcium, and phosphorus composition. Although somewhat dissimilar from the human fetus in respect to potassium, magnesium, iron, and "chemical maturity," the fetal guinea pig may serve as an excellent model for the study of fetal and perinatal fat metabolism.

Acknowledgments. The authors thank Wells Moorehead, M.D., Ann Rasmussen, B.S., Debra Reyman, B.S., Helen Moorehead, Ph.D. and George Hage, B.S. for their technical assistance, Pao-lo Yu, Ph.D. for statistical assistance and Jeannette Love and Carol Blue for manuscript preparation. We also thank Katrina Engle for her encouragement and support during this project.

\section{REFERENCES}

1. Battaglia FC, Meschia G 1978 Principle substrates of fetal metabolism. Physiol Rev 58:499-527

2. Southgate BAT, Hay BN 1976 Chemical and biochemical development of the human fetus. In: Roberts DR. Thomson AM (eds) The Biology of Human Fetal Growth, Taylor and Francis Ltd, London, pp 195-209

3. Culmo RF 1972 The microdetermination of sulfur with an automatic elemental analyzer. Microchem J 17:499-507

4. Simon W, Sommer PF, Lyssy GH 1962 Complete automation of the microdetermination of carbon and hydrogen in organic compounds. Microchem J 6:239-258

5. Condon RD 1966 A new automatic organic elemental analyzer. Microchem J 10:408-426

6. Reeck GR. Fisher L 1973 A statistical analysis of the amino acid composition of proteins. Int J Peptide Protein Res 5:109-117

7. Sparks JW, Girard JR, Callikan S, Battaglia FC 1985 Growth of the fetal guinea pig: physical and chemical characteristics. Am J Physio 248:E132-139

8. Ziegler EE, O’Donnell AM, Nelson SE, Fomon SJ 1976 Body composition of the reference fetus. Growth 40:329-341

9. Rattray PV, Garrett WN, East NE, Hinman N 1974 Growth, development and composition of the ovine conceptus and mammary gland during pregnancy. J Anim Sci 38:613-626

10. Ferrell CL, Laster DB, Prior RL 1982 Mineral accretion during prenatal growth of cattle. J Anim Sci 54:618-624

11. Draper RL 1920 The prenatal growth of the guinea pig. Anat Rec 18:369-372

12. Adolph EF, Heggeness FW 1971 Age changes in body water and fat in fetal and infant mammals. Growth 35:55-63

13. Bohr C 1900 Der respiratorische stott wechseldes jangethierembryo. Skund Arch Physiol 15:413-424

14. Sparks JW, Girard JR, Battaglia FC 1980 An estimate of the caloric requirements of the human fetus. Biol Neonate 38:113-119

15. Widdowson EM, Spray CM 1951 Chemical development in utero. Arch Dis Child 26:205-214

16. Sheng HP, Huggins RA, Garza $\mathrm{C} 1982$ Chemical maturation in growing guinea pigs. Am J Physiol 242:R390-R393

17. Spray CM, Widdowson EM 1950 The effect of growth and development on the composition of mammals. Br J Nutr 4:332-353 